\title{
Artistic project as an example of new forms of children's education in the scope of culture competencies
}

Katarzyna Ziolowicz ziolodom@tlen.pl

The Jan Kochanowski University of Humanities and Sciences in Kielce, Poland

Reference

Ziolowicz, Katarzyna; (2012) "Artistic project as an example of new forms of children's education in the scope of culture competencies", p. 337-341. In: Barbosa, Helena; Quental, Joana [Eds]. Proceedings of the 2nd International Conference of Art, Illustration and Visual Culture in Infant and Primary Education. São Paulo: Blucher, 2015.

ISSN 2318-695X, ISBN: 978-989-98185-0-7

DOI 10.5151/edupro-aivcipe-64

The article discusses the changes in Pre-school Core Curricula in Poland and shows the strong and weak points of the new educational system. These recently formulated objectives compel educational actions which support the process of institutionalised acculturation from an early age. Due to the fact that compulsory education in Poland begins at the age of five, it was necessary to transform the pre-school core curriculum. There have been introduced crucial changes to the broadly taken field of visual arts education. A young person is supposed to be naturally introduced into the word of art from an early age, so as to be later on aware of one's country's cultural heritage and to feel responsible for it.

Experimental activities carried out in the Institute of Fine Arts UJK within the project Meetings with Art for the Youngest are an attempt to establish new forms of plastic art education at preschool. The teacher is supposed to leave the didactic and enter the sphere of cultural animation. The project supports the offer prepared by pre-school institutions and it is a crucial element of integration between the Institute and the local community.

The children showed much interest in acquiring knowledge by means of active participation. It confirms the higher effectiveness of activating methods compared to expository ones. The use of other materials and techniques contributed to the break out of creative energy and the development of an individual. The children who participated in the project are open to new ideas and willing to they experiment themselves. It should be noted that the recipients of our project are not only the children. During the activities the teachers acquire new experiences, which will help them prepare new teaching programmes. The impact of the project may be perceived also in the children's family environment, there were observed the parents' positive reactions to the exhibited works, their real interest and the use of them in positive reinforcement.

It is necessary to re-evaluate certain aspects of the form and content of contemporary education. In many countries the educational systems have been created to promote a departure from the education basing on retrieval of previously memorised knowledge for the sake of the education of key competencies. Such a situation has been prompted by the constantly changing reality, especially technical progress. The previous model of education has seemed insufficient. The Council of Europe and European Parliament agreements, signed in 2006, obliged Poland to educate key competencies.'

As a result, the general education programmes have been modified. Each school subject has been revised to give students adequate knowledge. The knowledge is to be formed and deepened at future educational stages when the student acquires necessary skills and social competencies. 
In the process of forming key competencies we have agreed to prepare children and youths to the active participation in culture, both as a recipient and creator of new forms and visual activities. On the one hand, the educational basis is the region's or country's material heritage, on the other hand, the art workshops which offer the possibility of active participation in the role of creator.

These recently formulated objectives compel educational actions which support the process of institutionalised acculturation from an early age. Due to the fact that compulsory education in Poland begins at the age of five, it was necessary to transform the pre-school core curriculum. There have been introduced crucial changes to the broadly taken field of visual arts education. A young person is supposed to be naturally introduced into the word of art from an early age, so as to be later on aware of one's country's cultural heritage and to feel responsible for it. Such a person in the future undertakes a number of activities to support and increase the heritage.

It is stated in the curriculum:

A child who attended a pre-school institution and begins primary school education:

Shows to the best of his or her abilities interest in monuments, works of art, traditions and folk customs of a particular region.

Uses various techniques of artistic expression and a range elementary means of expression (such as shape or colour) creating simple compositions and designs.

Shows interest in painting, sculpture and architecture (including green and interior architecture $)^{2}$

The changes resulted from the need of providing equal educational opportunities for children living in various places. The curriculum has become at the same time the standard of requirements.

The extent of knowledge and skills which are to be acquired by a child requires the application of new forms of plastic arts education. Graphomotor exercises (using stencils or colouring pages), which constitute a major part of school curriculum ( ca. $90 \%$ out of all exercises) should be substituted for the first contacts with art in museums and galleries and the introduction of a number of artistic techniques which develop children's natural creativity. There emerges a (rhetorical) question whether teachers are prepared to such a form of education. Is their knowledge in the field of visual arts sufficient? Which methods will be the most effective?

The educational resources in pre-school institutions are not adequate. Traditional didactic means may only complement the process of education. Teachers and theoreticians have started searching for new solutions. The kindergarten seems to be the last and only place which still resorts to the old educational methods. While schools have been radically changing their didactic resources, the classical model prevails in pre-school education. The difference is clearly visible in the offer of private institutions, as they introduce many attractive educational activities: sports, dance, foreign languages, drama, cookery, speech therapy, dog assisted therapy, sign language for the youngest, arts or music. ${ }^{3}$ Only one pre-school (out of nine which have been analysed) has noticed in its educational programme the importance of arts education and has introduced ceramics classes. The state owned institutions offer extra-curricular activities only in the form of non-obligatory, additionally paid classes. Basing on the gathered materials, it can be observed that despite the changes imposed by Legal Acts, the pre-school curricula still lack forms and methods which would provide equal educational opportunities. Actually, education has been acquiring a commercial character.

Cultural education institutions such as museums or galleries prepare a didactic offer which is to support and supplement the activities resulting form the Legal Acts and aimed at pre-school children. The project Culture Map, which has become the priority of the Ministry of Culture and National Heritage, is carried out to improve the quality of aesthetic education in kindergartens and schools. The effects of the project include: the changes in school curricula and the creation 
${ }^{\circ}$ Congresso Internacional

de Arte, llustracão e Cultura Visual

na Educação Infantil e Primária

of the web portal which provides information for teachers and children but also gives examples of good practices.

Experimental activities carried out in the Institute of Fine Arts UJK within the project Meetings with Art for the Youngest are an attempt to establish new forms of plastic art education at a pre-school level. The teacher is supposed to leave the didactic and formational role and move on to the sphere of cultural animation. The main objective of the project is the implementation of the plastic arts educational curriculum, as well as the preparation of a young person to take on various roles in relation to the arts: the viewer, the animator and the creator. The project supports to a great extent the didactic offer prepared by pre-school institutions and it is a crucial element of integration between the Institute and the local community which affects its development. The fact that the kindergarten is located in the same part of the city as the Institute contributes to the attractive character of our offer and enables frequent contacts. The participants in the projects are students of Art Education in the Field of Plastic Arts, who at the same time develop their professional skills in the scope of culture animation.

The project included three cultural activities:

\begin{abstract}
1 Education through the contact with a work of art in a gallery - the venue was Gallery XS in the Institute of Fine Arts UJK. The main objective was the creation of visual perception skills which were inspired and whetted by the teacher.
\end{abstract}

2 Practical exercises developing divergent thinking. Its important element was the development of artistic expression by means of a play where the main stress is put on teaching through one's own practical experience.

3 Observation of visual artists' workshop in their studios in the Institute of Fine Arts. That is 'I know = I understand how it works.'

The activities from the first sphere included the children's participation in temporary exhibitions organised by the Institute of Fine Arts. The children were invited to visit the exposition while the guide was telling them about the artworks, paying attention to their theme and form, and forming aesthetic evaluation considering various aspect ( technological, aesthetic or artistic means).The pre-schoolers viewed the works created by adults, students and other children. They were able to perceive the art using their all senses. The children touched the exhibits, manipulated with them, occasionally commenting on olfactory experiences. The exhibits were equally appreciated by the pre-school teachers. It was possible for the children to get acquainted with various means of artistic expression, both abstract and realistic art. The most enthusiastically was accepted the exhibition of children's art.( II. 1,2,3) If one analyses methodological publication prior to 1999, it can be observed that one of the elements of aesthetic education was considered the formation of visual perception skills. At pre-school age the most frequent is spontaneous perception that turns into directed perception under the influence of educational processes, both formal (pre-school, school) and informal ones ( home, the media). In order to reach the other form of perception, a child should have the opportunity to see original works of art or their reprints. The presentation should be accompanied with adequate theoretical knowledge which enables the children observation of other than just material aspects of the work of art. These tasks have been a response to the new core curriculum which states that children should be prepared to create their interest in art and should attempt to express their opinions on art.

The activities from the second sphere were held in the Institute of Fine Arts and in the kindergartens. We attempted to indicate how different may be plastic arts classes so as they could develop creative thinking. There were deliberately chosen the techniques which are not particularly popular in every day pre-school education, they included: graphics, decoupage, wax decalcomania, pottery and ceramics.(Il.4,5) The methods used during the classes involved the presentation of the technique by an adult, followed by the children's individual activities. Wiesław Karolak emphasises the importance of play in the aesthetic education, presenting a series of activities developing creative thinking. Karolak bases these activities on recent achievements of psychology, especially imagination training. One should take into account the psychological idea that in fact creativity accompanies human beings in various aspects of existence and it is a valuable characteristic because it contributes to the development of an individual and a civilisation. Consequently, such a characteristic should be formed and 
$2^{\text {nd }}$ International Conference Art, Illustration and Visual Culture in Infant and Primary Education
Il.1 Exibition of children's art- the participants of artistic workshops organised by The Children's University.

Il.2 Exhibition- graphic arts diploma

II. 3 End of year exhibition

II. 4 Graphic arts classes at the Institute of Fine Arts

II. 5 Decoupage classes

II. 6 Visit to sculptor's studio trained. As a result, the proposed activities were typical for workshops which stimulated the development of creative thinking in the scope of different fluencies: thinking (fast and unconstrained formulation of a number of answers), verbal (generation of words from the memory resources), associational ( giving adjectives for specific words - in our case - works of art.), expressional (the ability to form a whole out of many elements), figurative ( the ability to create new projects), ideational (notion of rapidity in the application of specific elements) (J.P. Guilford, q.a. T. Lewowicki 1980). The works which were made during the activities were valuable as an expression of creative play, yet they did not have any aesthetic values, thus they were sometimes underestimated by the teachers who expect precision and correctness and most frequently use reproductive graphomotor exercises.

During one of our activities, the children were given paint in three basic colours. Their task was to mix the paint and obtain as many colours as possible. Then they were supposed to use these colours creating a painting of their choice. The experience of change thrilled the children, the fact of obtaining a new colour was more important than what the children painted. This activity made it possible to observe an interesting phenomenon. A boy, perceived by the teachers as 'less talented', made the best and most interesting work, obtaining many secondary colours. His previous works, colouring pages, were not too precise and they were evaluated as worse. There may be raised a question whether the creative potential of an individual is not destroyed by means of schematic exercises. ( see: E. Nęcka)

The artist's workshop seems to be commonly known but it caused a lot of sensation among the youngest. The children were able to touch brushes, palettes, chisels or a graphic press, which was impossible to do in the kindergarten. (II.6,7) Galleries and museums offering activities for children focus on artistic activities and worksheets that correspond to the current exposition. They do not give the chance to know the art from the workshop perspective.

Even though I mentioned above three spheres of activities, in practice they were carried out together. Frequently, a visit to an exhibition ended in creative activities in the course of which children learned about the artist's workshop.
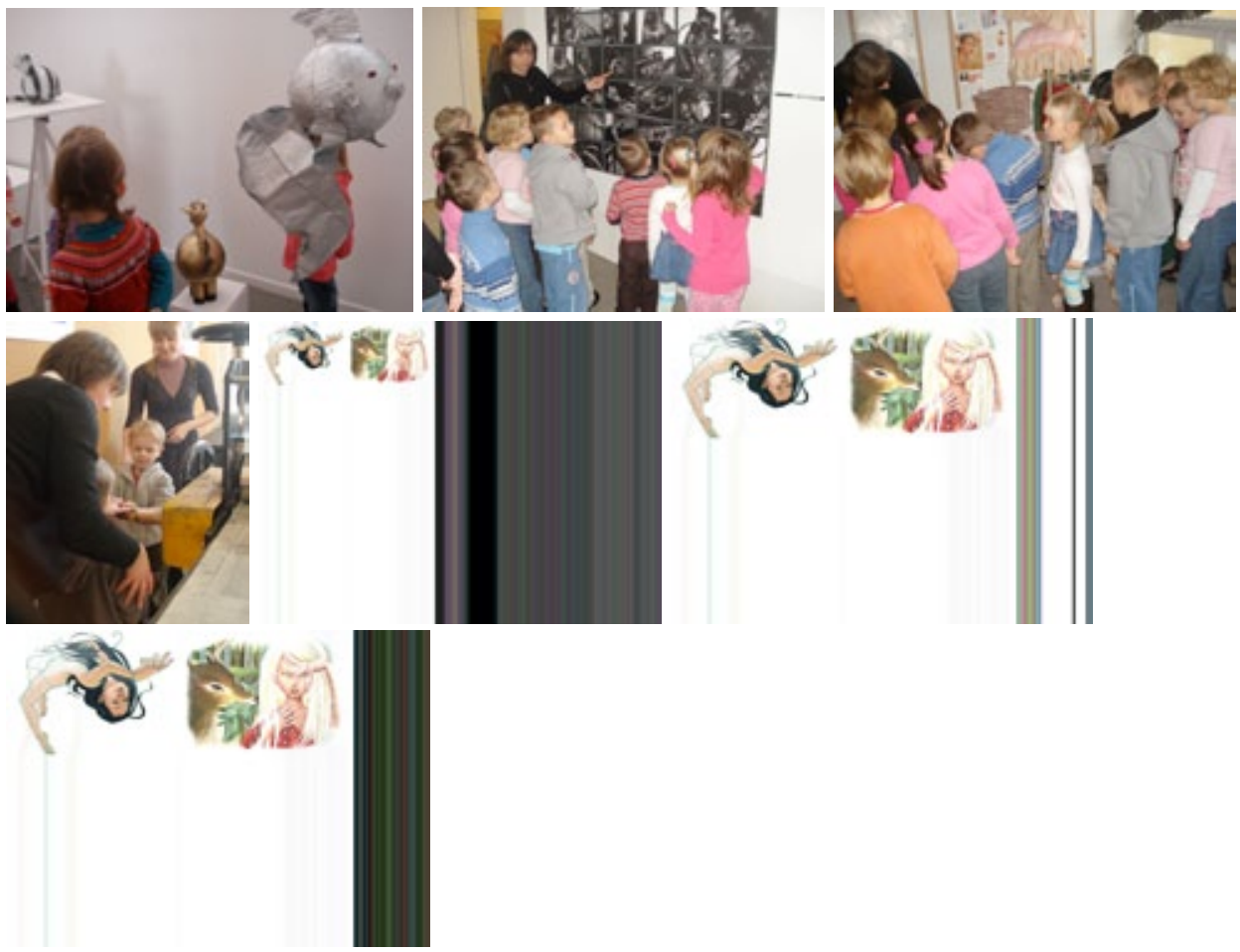
$2^{\text {nd }}$ International Conference Art, Illustration and Visual Culture in Infant and Primary Education $2^{\circ}$ Congresso Internacional

de Arte, Ilustração e Cultura Visual

na Educação Infantil e Primária

\section{Conclusion}

The activities mentioned above have given rise to a number of conclusions based on preliminary observations. The children showed much interest in acquiring knowledge by means of active participation. It confirms the higher effectiveness of activating methods compared to expository ones. The use of other materials and techniques contributed to the break out of creative energy and the development of an individual. Children who participated in the project are open to new ideas and experiments. The problem is the stereotypical way the teachers evaluate children's work: they find it difficult to appreciate the manifestations of free expression and creative search.

The exhibitions were children-friendly, they could perceive the exhibits involving all their senses, not only the sight - but also they could smell or touch the artworks. As a result, the children felt free to express themselves in speech. What is more, the children were truly interested in art and brought their parents to the gallery in the Institute. In fact, they helped to promote our Center. The children showed much more openness to contemporary art than the teachers who had not been acknowledged with art theory.

In case of practical exercises, the children reacted spontaneously to the shift from well-known stencils or colouring pages. Even those who were not previously interested in plastic arts did not want to stop their work. In consequence, the activities took more time than it was outlined in methodological indications. The problem was solved by the choice of forms and methods, e.g. simultaneous exercises in groups, and the use of combined tasks - first the exhibition, then movement-based activities and finally creative work.

The interest of pre-school teachers confirms the relevance of the tasks undertaken by us. While at the first stages we were looking for institutions which would like to cooperate with us, now the pre-school institutions eagerly declare their willingness to participate in the project. At this point, it should be noted that the actual recipients of our project are not only the children who attend kindergartens. During the activities the teachers acquire new experiences, which later on affects the preparation of teaching programmes. The impact of the project may be perceived also in the children's family environment. Another valuable observation were the parents' positive reactions to the exhibited works, their real interest and the use of them in positive reinforcement.

There can be drawn one more conclusion: we must educate adults so as to make them appreciate the value of their children's artworks which will result in open and creative attitudes of young people.

\section{Bibliography}

1. Nowa Podstaw Programowa, Załącznik nr 5i7. MEN 2008 (Core Curriculum for Preschool Institutions, Appendix no.5 \&7)

2. T. Marciniak, Problemy wychowania plastycznego, 1976

3. S.Popek, (red), Metodyka nauczania plastyki w klasach początkowych, 1984

4. A. Pełzowski, Plastyka w klasach I-III szkoły podstawowej, 1986

5. H. Hohensee- Ciszewska, Powszechna edukacja plastyczna,1982

6. W. Karolak, Moje portrety,2002

7. W. Karolak, Projekt edukacyjny - projekt artystyczny,2004

8. W. Karolak, Sztuka jako zabawa, zabawa jako sztuka,2000

9. E. Necka, Trening twórczości, 1998

10. T. Lewowicki, Kształcenie uczniów zdolnych, 1980 